\title{
Psychiatric disorders in patients with systemic lupus erythematosus
}

Transtornos psiquiátricos em pacientes com lúpus eritematoso sistêmico

Nadja Maria Jorge Asano

Programa de Pós-Graduação em Neuropsiquiatria e Ciências do Comportamento, Psiquiatria, na Universidade Federal de Pernambuco (UFPE), 2011 , Tese de Doutorado.

Orientador: Prof. Dr. Otávio Gomes Lins

Coorientador: Profa. Dra. Maria das Graças Wanderley de Sales Coriolano

Correspondence: Rua Silveira de Carvalho 252; 52110-060 Recife PE - Brasil; E-mail: nadjaasano@hotmail.com

\begin{abstract}
Background: The frequency of psychiatric disorders associated with systemic lupus erythematosus (SLE) is variable. Objective: To identify the psychiatric disorders of patients with SLE. Methods: The Mini International Neuropsychiatric Interview Plus was used in 131 women for the diagnosis of psychiatric disorders related with age, time and activity of the disease (SLEDAI-2K). Eighty women with SLE and 60 healthy women were genotyped by polymerase chain reaction. In 113 patients, the SF-36 was evaluated. Results: Major depressive episode (37.4\%), Agorafobia (45.0\%) and generalized anxiety disorder (34.4\%) were the most common findings. Activity of the SLE was significantly associated with the presence of humor disorders, disorders of anxiety and suicide risk ( $p<0.05$ ). Humor disorders, anxiety disorders and suicide risk presented greater tendency to the G/G genotype. The domains of SF-36 for physical function, vitality and mental health had significant results for all the disorders ( $p<0.05)$. Conclusions: The activity of the SLE represented risk for the presence of humor and anxiety disorders. This study has presented evidences of the association between polymorphism in the promoter - 174 G/C of the gene IL-6. All SF-36 domains were shown to be related with psychiatric disorders.
\end{abstract}

Key words: lupus erythematosus, systemic; mental disorders; quality of life; interleukin-6; cytokines; polymorphism, genetic. 